\title{
PENGARUH KOMPOSISI CAMPURAN BATU BARA LOKAL DAN IMPOR TERHADAP KUALITAS KOKAS PT ABC
}

\author{
"Safril Kartika Wardana, Babay Bayquni, M. Guntur Perkasa, dan Zikri A. Wafi \\ Program Studi Teknik Kimia, Fakultas Teknik, Universitas Serang Raya \\ Jl. Raya Serang - Cilegon KM 5 Drangong, Kecamatan Tatakan, Serang, Banten, Indonesia \\ "Email: safril@unsera.ac.id
}

\begin{abstract}
Abstrak
Kokas merupakan hasil karbonisasi batu bara tanpa kontak udara yang menyebabkan berkurangnya kandungan zat terbang pada batu bara sehingga nilai karbon tertambatnya menjadi meningkat. Kokas digunakan sebagai bahan bakar dan bahan pereduksi besi dalam proses pembuatan baja dalam teknologi blast furnace. Kokas yang digunakan harus memenuhi parameter kimia dan fisik yang dipersyaratkan karena memiliki peranan penting dalam meningkatkan produktifitas pembuatan baja. Parameter kimia yang dibutuhkan pada kokas yaitu nilai kadar air, kadar zat terbang, kadar abu, kadar karbon tertambat, sedangkan untuk pengujian kualitas kokas didasarkan pada dua indek degradasi yaitu CRI (coke reaction index) dan CSR (coke strength after reaction). Tidak semua batu bara lokal memiliki kualitas yang memenuhi parameter yang dipersyaratkan, seperti batu bara Adaro dan Marunda Graha Mineral (MGM) dari Kalimantan yang memiliki kualitas dibawah standar yang dipersyaratkan. Penelitian ini bertujuan untuk mendapatkan batu bara sesuai dengan standar yang dipersyaratkan PT ABC melalui pencampuran atau blending batu bara lokal dengan batu bara impor German Creek 8 (GC-8) dan Moranbah North (MN) yang memiliki kualitas yang lebih bagus. Proses karbonisasi dilakukan pada suhu $1000^{\circ} \mathrm{C}$ selama 1 jam dalam suatu tungku. Variasi komposisi yang dilakukan sebanyak tiga variasi. Selanjutnya kokas hasil karbonisasi dilakukan pengujian. Dari beberapa parameter kualitas kokas yang dipersyaratkan oleh PT ABC didapat hasil kadar air ketiga variasi sampel masih memiliki kadar air yang dipersyaratkan yaitu dibawah 4\%, Kadar zat terbang ketiga variasi sampel masih memenuhi nilai yang dipersyaratkan yaitu $<1,25 \%$, Kadar abu ketiga variasi sampel masih memenuhi nilai yang dipersyaratkan yaitu $<12 \%$, Nilai Coke Reactivity Index (CRI) ketiga variasi sampel tidak ada yang memiliki Nilai CRI yang dipersyaratkan yaitu memiliki nilai $<25 \%$ dan Nilai Coke Strength Reactivity (CSR) ketiga variasi sampel tidak ada yang memiliki Nilai CSR yang dipersyaratkan yaitu memiliki nilai >65\%. K3 adalah kokas dengan kualitas terbaik dengan nilai karbon tertambat sebesar 88,73\%.
\end{abstract}

Kata kunci: Batu Bara, CSR, CRI, Karbonisasi, Kokas

\section{PENDAHULUAN}

Blast furnace merupakan salah satu teknologi pada pembuatan baja yang sedang dikembangkan oleh PT ABC untuk memenuhi kebutuhan baja nasional. Salah satu bahan baku yang digunakan pada teknologi ini adalah kokas yang berfungsi sebagai bahan bakar. Kokas diperoleh dari pemanasan batu bara dalam Coke Oven Battery (oven tertutup) melalui proses karbonisasi dan penghilangan kadar volatile material dengan suhu tinggi (PT ABC, 2016).

Kokas yang digunakan dalam teknologi blast furnace harus memenuhi parameter kimia dan fisik yang dipersyaratkan karena memiliki peranan penting dalam meningkatkan produktifitas pembuatan baja. Parameter kimia yang harus diperhatikan pada kokas yaitu nilai kadar air, kadar zat terbang, kadar abu, kadar karbon tertambat, kadar sulfur dan fosfor (Diez et al. 2001). Selain itu menurut Ocheri (2017), pemilihan komposisi sebuah campuran batu bara termasuk parameter kimia dan fisik batu bara yang digunakan pada saat karbonisasi di dalam oven (suhu tinggi dan tertutup) akan menghasilkan kokas dengan kualitas yang tinggi untuk pengecoran logam di blast furnace.

Menurut (Bernal et al. 2011) kualitas campuran batu bara yang digunakan untuk pembuatan kokas memiliki nilai kadar karbon tertambat (FC) sebesar $69,75 \%$ yang menghasilkan kokas dengan nilai FC sebesar 91,10\%. Sedangkan kualitas batu bara yang digunakan Coke Oven Plant PT ABC memiliki nilai FC sebesar 65-69\%. Batu bara jenis ini di Indonesia tidak semua memiliki kualitas yang sama seperti diatas bahkan memiliki kualitas di bawah standar yang dipersyaratkan untuk dijadikan bahan baku pembuatan kokas, seperti batu bara PT Adaro dari Tanjung Tabalong, Kalimantan Selatan yang memiliki nilai FC sebesar $52 \%$. 
Penelitian ini bertujuan untuk mendapatkan batu bara sesuai dengan standar yang dipersyaratkan PT ABC melalui pencampuran atau blending batu bara lokal dengan batu bara impor German Creek 8 (GC-8) dan Moranbah North (MN) yang memiliki kualitas yang lebih bagus.

\section{METODOLOGI}

Sampel batu bara jenis GC-8, MN, Adaro dan MGM diambil dari stock yard masingmasing sebanyak $12 \mathrm{~kg}$, kemudian dimasukkan ke dalam alat Jaw Crusher. Jaw Crusher berfungsi untuk menghancurkan batu bara dengan tekanan tertentu sehingga dihasilkan batu bara dengan ukuran yang lebih kecil. Batu bara yang telah dihancurkan sebanyak $10 \mathrm{~kg}$ untuk bahan penelitian (GC-8, MN, Adaro dan MGM) dan $2 \mathrm{~kg}$ untuk pengujian kadar air total (GC-8, MN, Adaro dan MGM).

Proses blending batu bara GC-8, MN, Adaro dan MGM -A dilakukan dengan metode Areal Stockpile yaitu material yang akan diblending dicurahkan selapis demi selapis secara horizontal yang setiap perlapisan diratakan terlebih dahulu kemudian kemudian dicurahkan lapisan berikutnya demikian seterusnya (Anwary et al. 2014). Variasi komposisi yang digunakan adalah sebagai berikut:

Tabel 1. Variasi komposisi batubara

\begin{tabular}{lccc}
\hline \multirow{2}{*}{$\begin{array}{c}\text { Jenis batu } \\
\text { bara }\end{array}$} & \multicolumn{3}{c}{ Variasi Komposisi (\%) } \\
\cline { 2 - 4 } & K1 & K2 & K3 \\
\hline $\begin{array}{l}\text { GC-8 } \\
\text { (German }\end{array}$ & 25 & 25 & 15 \\
$\begin{array}{l}\text { Creek-8) } \\
\text { MN }\end{array}$ & & & \\
$\begin{array}{l}\text { Moranbah } \\
\begin{array}{l}\text { North) } \\
\text { Adaro }\end{array}\end{array}$ & 40 & 20 & 10 \\
$\begin{array}{l}\text { MGM } \\
\text { (Marunda }\end{array}$ & 10 & 10 & 15 \\
$\begin{array}{l}\text { Graha } \\
\text { Mineral) }\end{array}$ & 25 & 45 & 60 \\
\hline
\end{tabular}

Batu bara yang sudah dicampur dari masing-masing variasi ditimbang sebanyak 50 gram pada setiap cawan yang akan digunakan untuk proses pembuatan kokas, kemudian cawan tersebut dilakukan pemanasan di dalam Muffle furnace pada suhu $1000^{\circ} \mathrm{C}$ selama $2 \mathrm{jam}$.

\section{HASIL DAN PEMBAHASAN}

Tabel 2. Hasil analisis batu bara

\begin{tabular}{lcccc}
\hline \multirow{2}{*}{$\begin{array}{c}\text { Jenis } \\
\text { analisis }\end{array}$} & \multicolumn{2}{c}{ Hasil Analisis $(\%)$} & $\begin{array}{c}\text { Nilai yang } \\
\text { dipersyaratkan } \\
\text { PT ABC (\%) }\end{array}$ \\
\cline { 2 - 4 } & $\mathbf{K 1}$ & $\mathbf{K 2}$ & $\mathbf{K 3}$ & $<4$ \\
\hline Kadar Air & 0,12 & 0,24 & 0,35 & $<1,25$ \\
$\begin{array}{l}\text { Kadar zat } \\
\text { terbang }\end{array}$ & 0,65 & 0,87 & 1,02 & $<12$ \\
$\begin{array}{l}\text { Kadar } \\
\text { Abu }\end{array}$ & 10,58 & 11,94 & 10,31 & \\
$\begin{array}{l}\text { Coke } \\
\text { Reactivity }\end{array}$ & 32,5 & 35,3 & 39,9 & $<25$ \\
$\begin{array}{l}\text { Index } \\
\text { Coke }\end{array}$ & & & & \\
$\begin{array}{l}\text { Strength } \\
\text { Reactivity }\end{array}$ & 55 & 39,3 & 49,5 & $>65$ \\
\hline
\end{tabular}

Kandungan air dalam kokas berpengaruh terhadap kualitas kokas itu sendiri terutama saat penggunaanya di dalam blast furnace, semakin besar nilai kadar air yang terkandung dalam kokas tersebut maka kokas yang dibutuhkan akan lebih banyak dibandingkan kokas dengan kadar air yang lebih rendah (Diez et al. 2001). Hal ini dikarenakan nilai dari karbon tertambat dalam kokas tersebut menurun atau lebih kecil sehingga nilai kalor yang dihasilkan dalam proses pemanasan semakin kecil pula. Kadar air yang tinggi dalam kokas disebabkan proses quenching atau penyemprotan ketika kokas panas telah selesai dimasak.

Menurut (Leonardo et al, 1996), kadar air yang dipersyaratkan suatu kokas untuk digunakan di blast furnace yaitu dengan rentang 1-6\% sehingga dalam penelitian ini dari ketujuh variasi sampel masih memiliki kadar air yang dipersyaratkan.

Kadar air dalam kokas juga dipengaruhi oleh faktor lingkungan seperti kelembaban pada saat proses karbonisasi ataupun pada saat preparasi sampel. Berdasarkan hasil analisa kadar air dapat dilihat bahwa kadar air dalam sampel K1, K2 dan K3 berturut-turut adalah $0,12 \%, 0,24 \%$ dan $0,35 \%$ sehingga masih berada dalam batas yang dipersyaratkan oleh PT ABC.

Kandungan zat terbang dalam kokas mempengaruhi kesempurnaan pembakaran dan intensitas api yang dihasilkan oleh batu bara/kokas. Hal ini didasarkan perbandingan antara kandungan karbon tertambat dan zat terbang, yang disebut rasio bahan bakar (fuel ratio). Semakin tinggi nilai rasio bahan bakar, semakin banyak juga jumlah karbon di dalam batu bara yang tidak terbakar. Jika perbandingan itu lebih dari 1,2, maka 
pengapian tidak akan optimal sehingga kecepatan pembakarannya akan menurun (Arif, 2014). Selain itu kandungan zat terbang yang tinggi dalam kokas akan berpengaruh terhadap pemurnian blast furnace gas (BFG) ataupun coke oven gas (COG). Semakin besar nilai kandungan zat terbangnya maka semakin sulit dalam proses pemurnian kedua gas tersebut diakibatkan kandungan zat organik dalam gas masih banyak (Diez et al. 2001).

Menurut (Leonardo et al, 1996) kokas yang akan digunakan untuk blast furnace harus memiliki kandungan zat terbang sebesar $1 \%$, sedangkan yang dipersyaratkan PT ABC sebesar $1,25 \%$.

Berdasarkan hasil analisa kadar zat terbang didapatkan bahwa kadar zat terbang dalam sampel K1, K2 dan K3 berturut-turut adalah $0,65 \%, 0,87 \%$ dan $1,02 \%$ sedangkan nilai yang dipersyaratkan adalah maksimal sebesar $1,25 \%$ sehingga masih berada dalam batas yang dipersyaratkan oleh PT ABC.

Abu mewakili mineral yang terkandung di batu bara, selain zat anorganik yang mudah menguap. Abu terbentuk sebagai salah satu hasil sisa bakaran batu bara yang terdiri dari berbagai oksida logam pembentuk batuan, seperti aluminium dan besi. Batu bara juga bisa mengandung pengotor luar, yaitu material anorganik yang terbawa saat proses penambangan. Semakin tinggi kandungan abu, semakin rendah kualitas batu bara. Kandungan abu yang tinggi berarti nilai kalornya lebih rendah (kandungan energi per ton batu bara) (Arif, 2014).

Selain itu keberadaan abu dalam kokas yang digunakan untuk blast furnace bersifat sangat penting. Hal ini dikarenakan ketika kandungan abu meningkat maka produktifitas kokas dalam blast furnace menurun. Abu dalam kokas adalah komponen yang tidak diharapkan kehadirannya karena berpengaruh terhadap volume pembentukan slag dan mempengaruhi komposisi dari hot metal. Berdasarkan pengalaman di dunia industri menunjukan bahwa peningkatan $1 \%$ abu dalam kokas dapat mengurangi produksi hot metal sebesar $2-3 \%$ (Diez et al. 2001).

Berdasarkan hasil analisa kadar abu dalam sampel K1, K2 dan K3 berturut-turut adalah $10,58 \%, \quad 11,94 \%$ dan $10,31 \%$. Menurut Leonardo et al, 1996 bahwa kokas yang akan digunakan untuk blast furnace harus memiliki kandungan abu sebesar 8-12\%. Proses karbonisasi suatu batu bara dapat meningkatkan nilai abu pada kokas akibat dari pemanasan pada suhu tinggi, kadar abu yang diperoleh berada dalam rentang 10,31-11,94\% sedangkan nilai yang dipersyaratkan adalah $8-12 \%$ sehingga masih berada dalam batas yang dipersyaratkan oleh PT ABC.

Karbon tertambat atau sering disebut karbon stabil adalah karbon tetap yang tertinggal bersama abu bila batu bara dibakar tanpa oksigen dan setelah zat terbangnya habis. Karbon tertambat atau fixed carbon merupakan kandungan utama dari batu bara/kokas. Kandungan inilah yang paling berperan dalam menentukan besarnya heating value suatu batu bara. Semakin banyak kandungan karbon tertambatnya, maka semakin besar heating value-nya (Erna, 2012).

Berdasarkan hasil analisa nilai karbon tertambat pada sampel K1, K2 dan K3 berturutturut adalah $87,23 \%, 86,3 \%$ dan $88,73 \%$ sedangkan nilai yang dipersyaratkan yaitu minimal $81 \%$ sehingga hasil yang didapat memiliki nilai yang bagus dan dalam batas yang dipersyaratkan oleh PT ABC.

Sebagai akibat dari kenaikan temperatur dalam ruang gasifikasi maka zat-zat seperti air dan zat-zat yang mudah menguap lainnya yang terkandung dalam briket kokas sebagian akan terlepas keluar. Sebagai akibat terlepasnya sebagian material yang terkandung dalam bongkahan briket kokas dapat menyebabkan terjadinya penurunan massa secara keseluruhan (Khairil et al, 2014).

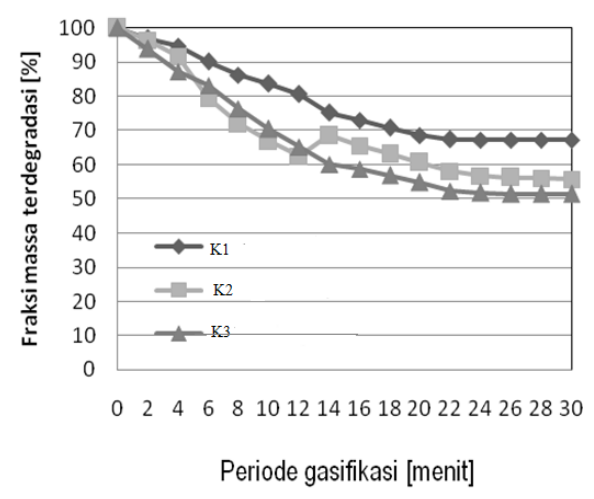

\section{Gambar 1. Profil fraksi penurunan massa kokas untuk jenis material dengan komposisi yang berbeda}

Fraksi penurunan massa akibat terdegradasi bertambah dengan bertambahnya periode gasifikasi dari kokas. Dari Gambar 1 dapat dilihat bahwa profil laju penurunan massa dapat dikarakterisasi dengan dua tahap penurunan 
massa yaitu tahap pertama dengan laju penurunan massa cepat dan diikuti dengan tahap kedua yaitu dengan laju penurunan massa yang lambat. Penurunan massa yang cepat barang kali diakibatkan oleh pelepasan kandungan air pada permukaan kokas, sedangkan penurunan massa yang lambat diakibatkan oleh pelepasan air terikat dalam kokas dan pelepasan zat-zat yang mudah terbang (volatile matter) lainnya.

Dari Gambar 1 juga dapat dilihat bahwa kokas dengan kode K3, dimana penurunan massa selama gasifikasi lebih cepat jika dibandingkan kokas dengan menggunakan komposisi material K2 dan K1 yang lebih lambat. Dengan demikian kokas dengan kode K3 kualitasnya lebih baik daripada K1 dan K2.

Berdasarkan hasil analisa coke reaktivity index pada sampel $\mathrm{K} 1, \mathrm{~K} 2$ dan $\mathrm{K} 3$ berturutturut adalah $32,5 \%, 35,3 \%$ dan $39,9 \%$. Nilai CRI yang diperoleh berada dalam rentang dan nilai yang dipersyaratkan yaitu maksimal $25 \%$. Menurut (Debjani Nag et al, 2009) kokas yang memiliki nilai reaktivitas yang tinggi akan cepat habis saat proses di blast furnace sehingga dibutuhkan lebih banyak kokas untuk bahan bakar dan mereduksi sinter ore.

Berdasarkan hasil analisa coke strength reaktivity pada sampel $\mathrm{K} 1, \mathrm{~K} 2$ dan $\mathrm{K} 3$ berturutturut adalah 55\%, 39,3\% dan 49,5\%. Menurut Debjani Nag et al, 2009 nilai CSR yang rendah akan mengakibatkan kokas tidak maksimal perannya sebagai bahan bakar karena pada saat proses handling kokas dimasukkan ke dalam blast furnace lewat atas apabila nilai kekuatan atau ketahanan kokas terhadap benturan kecil maka kokas akan mudah hancur dan lebih cepat habis terbakar, sehigga kekuatan kokas harus tinggi. Kode K1 memiliki nilai CSR paling tinggi meskipun begitu dari keseluruhan sampel yang memiliki rentang nilai $39,3-55 \%$, nilai yang di persyaratkan yaitu Min 65\% sehingga hasil CRI \& CSR yang didapat semuanya belum memenuhi spesifikasi yang dipersyaratkan PT ABC.

Kemungkinan penyebab yang terjadi diakibatkan pada saat proses karbonisasi yang kurang maksimal dari segi waktu dan suhu dan pada saat pembuatan kokas skala laboratorium menggunakan muffle furnace sehingga hasil pembentukan kokas tidak begitu baik, bisa juga dikarenakan proses karbonisasi terkontaminasi udara luar ataupun oksigen pada saat memasukkan batubara dalam cawan tertutup ke dalam muffle furnace yang bisa mengakibatkan kokas tidak terbentuk sempurna. Penyebab lain juga bisa dikarenakan preparasi pembentukan kokas dibentuk bulat dan tidak pipih untuk mencapai ukuran $19 \mathrm{~mm}$ - 22,4 mm dilakukan dengan cara dipalu dan menggunakan cetakan berbentuk lingkaran, sehingga kekuatan kokas dapat menurun karena adanya benturan dengan palu dan alat cetakan pada batu bara yang akan dibuat menjadi kokas.

\section{KESIMPULAN}

Dari beberapa parameter kualitas kokas yang dipersyaratkan oleh $\mathrm{PT} \mathrm{ABC}$ didapat hasil:

a. Kadar air: ketiga variasi sampel masih memiliki kadar air yang dipersyaratkan yaitu dibawah 4\%. Kode sampel K1 memiliki nilai kadar air yang paling rendah yaitu $0,12 \%$.

b. Kadar zat terbang: Dari ketiga variasi sampel masih memenuhi nilai yang dipersyaratkan yaitu $<1,25 \%$. Kode sampel K1 memiliki nilai zat terbang yang paling rendah yaitu $0,65 \%$

c. Kadar abu: dari ketiga variasi sampel masih memenuhi nilai yang dipersyaratkan yaitu $<12 \%$. Kode sampel K3 memiliki nilai kadar abu yang paling rendah yaitu $10,31 \%$.

d. Kadar karbon tertambat: Kode sampel yang memiliki nilai karbon tertambat paling tinggi adalah kokas dengan kode sampel K3 yaitu sebesar $88,73 \%$.

e. Nilai CRI: ketiga variasi sampel tidak ada yang memiliki Nilai CRI yang dipersyaratkan yaitu memiliki nilai $<25 \%$. Kode sampel K1 memiliki nilai CRI yang paling rendah yaitu sebesar $32,5 \%$.

f. Nilai CSR: ketiga variasi sampel tidak ada yang memiliki Nilai CSR yang dipersyaratkan yaitu memiliki nilai $>65 \%$. Kode sampel K1 memiliki nilai CSR yang paling tinggi yaitu sebesar 55\%.

\section{DAFTAR PUSTAKA}

PT ABC. (2016). Coke Oven Battery. PT ABC. Cilegon.

Anwary, F., Bahri, S., Yulhendra, D. (2014). Optimasi Pencampuran Batu bara Beda Kualitas Untuk Memenuhi Kriteria Permintaan Konsumen di PT. Allied Indo Coal (AIC) Sawahlunto, Sumatera Barat. Fakultas Teknik, Universitas Negeri Padang. Padang. 
Arif, I. (2014). Batu bara Indonesia. PT Gramedia Pustaka Utama. Jakarta.

Badan Standar Nasional Indonesia. (1998). Klasifikasi Sumberdaya dan Cadangan Batu bara. SNI 13-5014-1998. Jakarta.

Bernal, J. M. G., Pulido, W. F. M., Varela, L. I. R., Ramirez, J., Velasquez, J. D. (2011). Using Ultrafine Particles a Coal Washing Plant in Metallurgical Coke Production. Universitas National Colombia. Colombia.

Debjani Nag, S.K. Haldar, P. K. Choudhary, P.K. Banerjee. (2009) Prediction of Coke CSR from Ash Chemistry of Coal Blend R\&D Division, Tata Steel, Jamshedpur, Jarkhand India

Diez, M. A., Alvarez, R., Barriocanal, C. (2001). Coal for Metallurgical Coke Production: Prediction of Coke Quality and Future Requirements for Coke Making. International J. Coal Geology 50:389-412

Hasni, Manulang.H. (2011). Peranan Sektor Baja dalam Perekonomian Indonesia. Buletin Ilmiah Litbang Perdagangan 5:2223

Marsh, H. (1989). Introduction to Carbon Science. North Shield: Butterworth

Ocheri, C. (2017). Selection of Coals for Making High Quality Metalurgical Coke at Ajakuta Steel Company Limited. J. Powder Metall 6:150 